\title{
Çocuk Adam: Şairin tek romanı veya nostaljiyle kurgulanmış bir otobiyografi
}

\author{
Çocuk Adam (Child Man): The single novel of \\ the poet or an autobiography fictionalized with \\ nostalgia
}

\author{
Gönderim Tarihi / Received : 01.09.2020 \\ Kabul Tarihi / Accepted : : 28.05.2021 \\ Doi: https://doi.org/10.31795/baunsobed.789226
}

\section{Şener Şükrü YiĞiTLER ${ }^{1}$}

ÖZ: Orhan Seyfi Orhon Türk edebiyatında şiirleri ve gazete yazılarıyla tanınan ve hecenin beş şairinden biri olarak yerini koruyan önemli bir isimdir. Edebiyatın çeşitli türlerinde eserler veren Orhon'un şiirleri, mizah ve hiciv hikâyeleri, fıkraları ve biyografilerinin yanı sıra Çocuk Adam (1941) adlı bir romanı da vardır. Orhon'un, edebiyat tarihçilerinin ve araştırmacıların ilgisinden mahrum kalan bu tek romanı, taşıdığı yoğun biyografik içerik ve sanatçının hayatından manzaraları, hayat görüşünü ve sanat anlayışını sergilemesi bakımından önemlidir. Bunun yanında, Orhon'un, romanın adının da çağrıştırdığ çocukluk, çocuk kalmak, büyümek üzerine düşüncelerine yer verdiği roman, derin nostalji duygusuyla dikkati çeker. Şiirlerindeki canlı lirizm etkisiyle tanınan şairin bu eserinde roman sanatının elverdiği içerik ve teknik unsurlardan faydalandığı görülür. Romanının içeriksel malzemesini oluşturan geçmişi, canlı, devam eden ve bugünle bağlantısı olan bir cevher olarak değerlendirir. Nostaljik yanılsamanın etkisiyle hafıza, çocukluk, ev, kaybedilen masumiyete özlem gibi temaları işlerken geçmişi ve romanının otobiyografik malzemesini yeniden kurgular. Ancak daha ilgi çekici biçimde Orhon, 1965'te yapılan ikinci baskısında romanının üçüncü bölümünü tümüyle değiştirir. Bu makalede, Orhon'un başta bir rüya âlemi olarak çocukluğu sonradan kötülük tohumlarının atıldığı bir çağ olarak hatırlamasının yanı sıra, onu romanının en çarpıcı sahnelerini içeren üçüncü bölümü yeniden yazmaya iten muhtemel kurgusal, psikolojik nedenler ve toplumsal şartlar tartışılmıştır.

Anahtar Kelimeler: Orhan Seyfi Orhon, Çocuk Adam, Nostalji, Otobiyografi, Çocukluk.

ABSTRACT: Orhan Seyfi Orhon, one of the Five Poets of Syllable (Beş Hececiler), is an important figure in Turkish literature who is known for his poetry and newspaper articles. In addition to his poems, humor and satirical stories, articles, and biographies, he has a novel called Çocuk Adam (Child Man, 1941). This single novel, deprived of the interest of literature historians and researchers, is important in terms of exhibiting life parts and art world-view, and sense of its author due to his intense biographical content. Besides, Orhon's

${ }^{1}$ Doç. Dr., Bitlis Eren Üniversitesi/Fen Edebiyat Fakültesi/Türk Dili ve Edebiyatı Bölümü/Yeni Türk Edebiyat1 Anabilim Dalı, ssyigitler@gmail.com, https://orcid.org/0000-0002-7283-3621 
novel, as its title signifies, tells about childhood, being child and growing up with a deep sense of nostalgia. The poet, who is known for his lyrical influence in his poems, makes use of the content and technical opportunities of the art of novel. He uses the past, the content material of the novel as a living, continuing essence which holds its bonds with the present. He fictionalizes his past and the autobiographic material of the novel with the influence of nostalgic illusion while he deals with memory, childhood, home, and longing for innocence. But more interestingly, Orhon completely changes the third part of his novel in its second edition which was published in 1965. In this article, besides Orhon's recollection of childhood as a dream world, as an age in which the seeds of evil were planted, the possible fictional, psychological reasons, and social conditions that prompted him to rewrite the third chapter that includes the most striking scenes of his novel, are discussed.

Keywords: Orhan Seyfi Orhon, Çocuk Adam, Nostalgia, Autobiography, Childhood. 


\section{EXTENDED ABSTRACT}

\section{Literature Review}

Orhan Seyfi Orhon, one of the representatives of the movement known as the The Five Poets of Syllable (Beş Hececiler) in Turkish poetry, has also carried the versatility that he exhibited throughout his life to the field of literature. All of his poems published in his books and magazines were collected in Siirler (1970) two years before his death, Fiskeler (1922), which he compiled from his daily articles in newspapers, Asrî Kerem (1942) in which he adapted the story of Kerem and Asli to the present day, and Dün Bugün Yarn (1943) from which he collected some of his articles. He showed that he produced works in different fields of literature with his collections from Kulaktan Kulağa (1943) which he brought together some of his anecdotes published in newspapers, Hicivler (1951) where he criticized the politicians of the period, Düğ̈̈n Gecesi (1957) which consists of humorous stories, and biographies he wrote for some important poets of Turkish literature. Orhon's only novel Çocuk Adam (1941), which should be considered as important evidence of the literary diversity of his works, did not arouse as much interest as the works listed here, and did not attract the attention of literary researchers. The most important feature of this novel, which is one of the most important yields of Orhon's literary versatility summarized here -in the words of the author- is that it is loaded with intense autobiographical material and that it was republished in 1965 after having been partially modified by the author. The literary, historical and psycho-social reasons that pushed Orhon, one of the most important figures of Turkish poetry, to rewrite the last part of his single novel, which is stated by him to carry the traces of his life, constitute the main issue of this article.

\section{Findings and discussion}

Çocuk Adam (The Child Man, 1941), the most neglected work in his corpus, is a novel that he gave approximately the first thirty years of his life by hybridizing the memoir and novel genres. It is seen that the childhood and partly the youth years of the protagonist in this novel, which Orhon published for the first time in his early fifties, are based on the deep traces of Orhon's own life. The childhood memories of the hero of the novel, who, like Orhon, spent his childhood in Çengelköy, always consist of positive scenes. Çocuk Adam, which can be accepted as an autobiographical novel in terms of its first two parts, displays a feature based entirely on Orhon's fiction in the continuation of the narrative. The novel tells the narrator's transformation from a child into an adult, also fits the textual characteristics of the Bildungsroman and Künstlerroman genres. In the third chapter in which the main plot of the story begins to be told, leaving 
behind the memories of the protagonist, the concept of "child man", which is mentioned for the first time, imposes negative meanings on childhood. The sources of the disaster, which is also caused by the disintegration of his home as a result of his love affair with the typewriter girl whom he employs, are sought in childhood. Thus, childhood is mentioned for the second time in the narrative.

\section{Result}

Although it emerged in European languages in 1688, the word 'nostalgia', which seems to be used for the first time in Turkish in the early Republican period, was handled together with the concept of 'father's house', which was used as a metaphorical link between Ottoman children and Ottoman intellectuals in the final analysis of the study. It was noted that childhood, portrayed as an age of innocence in the first recall, was seen as a source of malice in the second recall. It was concluded that this could be a 'false memory' syndrome that occurs as a result of the 'nostalgic illusion' process. Another feature that makes Çocuk Adam interesting from a fictional point of view is that the last chapter of the book has been completely changed and republished twenty-five years after its first publication. The reason behind this may be that the novel was accepted by the readership of the period as an obligatory reflection of the author's biography. As an important indicator of this, it is noteworthy that the word 'nostalgia', which appeared in European languages in 1688, was used for the first time in Turkish in the early Republican period. This situation provides a metaphorical connection between the Ottoman child and the intellectual of the Republic, based on the fact that the word refers to the concept of 'father's house', which is often remembered in the novel. Childhood, which is depicted as an age of innocence in the father's house in the first remembering process mentioned above, is seen as a source of malice in the second recall. It is highly probable that this may be a 'false memory' syndrome that emerges at the end of the 'nostalgic illusion' process. The act of returning to his father's home, which Orhon also describes in his poem "Çengelköy", is an impossible attempt to settle accounts at a symbolic level. Thus, like the Tanzimat writer, who assumed the identity of a father in the society in the absence of political authority, that is, the Sultan, in the last period of the Ottoman Empire, the writer of the early Republican period understands that in the absence of the 'leader cult', he must assume a similar role towards the society. However, a very short time has passed since the new regime, and he has to accept his literary and cultural inadequacies, mental underdevelopment, and childish appetites with the confession of a "child man". In this striking example of the novel Çocuk Adam, in which a sketchy memory reveals a half-life, the disappointment of the modernization project in the early Republican intellectuals overflows the work's subconscious. 


\section{Giriş}

Türk şiirinde Beş Hececiler olarak anılan hareketin temsilcilerinden biri olan Orhan Seyfi Orhon, hayatı boyunca sergilediği çok yönlülüğünü edebiyat alanına da taşımıştır. Kitaplarında ve dergilerde çıkan şiirlerinin tamamı ölümünden iki yıl önce Şiirler (1970) kitabında toplanan Orhon, gazetelerdeki günlük yazılarından derlediği Fiskeler (1922), Kerem ile Aslı hikâyesini günümüze uyarladığ 1 Asrî Kerem (1942), makalelerinden bir kısmını topladığ Dün Bugün Yarın (1943), gazetelerde yayımlanmış fikralarından bir kısmını bir araya getirdiği Kulaktan Kulağa (1943), dönemin siyasilerini eleştirdiği Hicioler (1951), mizahî hikâyelerden oluşan Dü̈̆ün Gecesi (1957) ve Türk edebiyatının bazı önemli şairleri için yazdı̆̆ ürün verdiğini göstermiştir (Kahraman, 2007: 390). Orhon'un eserlerinin edebi çeşitliliğinin önemli bir kanıtı olarak değerlendirilmesi gereken Çocuk Adam (1941) adlı tek romanı burada sayılan eserler kadar ilgi uyandırmadığı gibi edebiyat araştırmacılarının da dikkatlerini çekmemiştir. Orhon'un burada özetlenen edebi çokyönlülüğünün en önemli verimlerinden biri olan bu romanın en önemli özelliği -yazarının ifadesiyle- yoğun bir otobiyografik malzemeyle yüklü olması ve 1941'de ilk kez yayınlanmasının ardından 1965' te yazar tarafından kısmen değiştirilerek yeniden basılmasıdır. Türk şiirinin önemli figürlerinden biri olan Orhan Seyfi Orhon'u, hayatından izler taşıdığını söylediği tek romanının son bölümünü yeniden yazmaya iten edebi, tarihsel ve psiko-sosyal nedenler bu yazının temel meselesini oluşturmaktadır.

\section{Şiirden romana devamlılıklar}

En fazla şair yönüyle tanınan Orhan Seyfi Orhon, "sevgi ve aşk şairi" olarak kabul edilir; şiirlerinde "aşk, sevgi ve kadın" temalarını sıklıkla işlediği görülür (Tuncer, 2003: 13). Çok sevilip bilinen ve bestelenmiş şiirlerinin etkisiyle de pekişen bu durum, Orhon'un temel insani duygu ve düşünceleri işlediği şiirlerinin geri planda kalmasına neden olur. Onun "Fırtına", "Kar" "Körfezde Mehtap", İlkbahar Türküsü" Horoz" "Su”, "Gelincikler" “Irmak”, "Kar", "Yağmur", "Serçeler", "Üç Dünya", "Üç Buut”, "Son Perde”, "İmân”, "İstanbul'un Fethi" gibi pek çok şiiri sevgi ve aşk temalarına yer vermeyen, doğa, insan, hayat ve tarih gibi daha sosyal temaları işleyen şiirlerdir. Orhon'un insan ve hayat söz konusu olduğunda aşk konulu şiirlerinden geri kalmayan bir lirizm tonuyla işlediği bu temalar onun nesirlerinde kendilerine daha çok yer bulurlar. Pek çok sanatçının edebi dünyasını üzerine kurduğu, kullanmaktan zevk duyduğu temaları farklı edebi türlerde aynı ustalık ve yoğunlukla işledikleri sıklıkla görülen bir durumdur. Orhan Seyfi Orhon'un eserleri de bunun 
iyi örneğidir. Onun "Çengelköy” adlı şiiri bu yazıda incelenen Çocuk Adam adlı romanın içeriğini manzum olarak sunması bakımından son derece ilginçtir.

Derin bir özlem duygusu ve kaybolan masumiyete ağıt diliyle yazılmış bu şiirinde Orhon, elli yıl boyunca uğramadığı çocukluğunun evine, evin bulunduğu semte geri dönerek eski günleri anar. Boğaziçi'nin her yeri bir parça değişmiştir. Ama Çengelköy hep şairin bıraktığı gibidir. Bahçeler, bağlar, ağaçlar, bostanlar, ağaçlar, evler, şairin doğduğu ev, bayram namazlarını kıldığı camii, her şey olduğu gibi yerindedir. Çengelköy'ün hiç değişmeyen tablosunda birer silik gölge gibi beliren eski tanıdıkları, komşuları tek tek anmaya geçtiğinde şairin hasreti daha çok artar. Eski Çengelköy'ün renkli simalarından oluşan bu albümde mahalle sakinleri şairin çocuk imgesinde yer ettikleri özellikleriyle anılırlar. Her birinin coşkun bir özlemle anıldığı bu dizelerde insanlar, sevgililer ve hatta hayvanlar bir çocuğun canlı hayal gücünün süzgecinden geçerek mekânın kendisiyle bütünleşirler. Bu dönüşüm, bütün nostaljik çarpıtmalarda olduğu gibi, ilkin, zamanın belli bir aşamasında yaşamış insanların zamana dönüştürülmesiyle mümkün olur. İnsanlar zamansallaşırlar; bir bak1ma, ölümsüzleşirler. Daha doğru bir ifadeyle, ölümsüz olmaları arzulanır. Ardından, nostaljik algının dehlizlerinde kristalleşerek donarlar ve tekrar vücut kazanırlar. Nostaljik bakış onları adeta mekânlaştırır. İnsanlar, Çengelköy'ün yalıları, kayıkları gibi pastoral, idilik bir tablonun kımıltısız parçalarına dönüşürler. Ancak, hayal kırıklığı tam da burada başlar. Çünkü insanlar yürürler, ölürler; gelip geçicidirler. Ağaçlar gibi kök salmazlar. Bu yüzden, şair aradığı insanların hiçbirini orada bulamaz.

"'Göçtü çoktan!' dediler

Anarak, ismini sordumsa kimi!

Daracık, kuytu sokaklarda gezip,

Aradım gençliğimi!" (Orhon, 1970: 107).

Şair, doğduğu evi, Çengelköy'ü değil, çocukluğunun ve ilk gençliğinin insanlarının peşindedir. Ancak boşuna bir çabadır bu. Kant, "nostaljik birinin her zaman hayal kırıklı̆̆ına uğgradığını çünkü dönmek istediği yerin gençliğindeki yer değil, gençliğinin kendisi olduğunu iddia eder; 'hayal kırıklı̆̆ına ŭ̆rar' ve böylece 'arzusundan kurtulur'". (Cassin, 2018: 29). Nostalji, burada, yaratıc1 imgelemin ölümle yegâne başa çıkma aracı olur. Boym'un dediği gibi, "Nostalji, ev diye adlandrulan mitik yeri yeniden inşa ettiğini iddia etmez." (2009: 88). Orhon'un şiirindeki parçalanmış fragmanlar ölüme karşı geçici bir teselli verirler. Çocukluğun evine dönme edimi, yani ölümle başa çıkma şeklindeki imkânsız arzu böylece, bir süreliğine de olsa, şairin yakasını bırakır. 


\section{Şairin romanı veya kurgulanmış otobiyografisi}

Orhon'un romanının biyografi-yoğun yapısı önemli eseri akla getirir. Otobiyografi türünün en önemli örneklerinden biri sayılan Goethe' nin (1749-1832) Yaşamımdan Şiir ve Hakikat (1811) adlı eseri sanatçının hayatının 1775 yılına kadar olan kısmını kapsar. Goethe bu eseri yazdığında altmış iki yaşındadır. Seksen üç yaşında hayata veda edecek olan sanatçının eserinde, kendi hayatıyla çağın ruhu (Der Zeitgeist) arasında gördüğ̈̈ özdeşlik ve yetişme çağına olgunluk çağının tecrübesiyle bakmanın özgüveni hâkimdir. Orhan Seyfi Orhon da Goethe gibi eserini olgunluk yıllarında (51 yaşında) yayımlar. Seksen bir yaşında hayatını kaybeden Orhon orta yaşlı sayılacağı yıllarda kendi hayatıyla yoğun benzerlikler gösteren bir roman kaleme alarak eserinin ne kadarının otobiyografik ne kadarının kurmaca olduğunu bir bakıma ele vermiş olur. Böylelikle, anılarını kaleme almamış sanatçının eserlerine ve onun hakkında yazılan biyografilere dayanarak, romandaki çocukluk yıllarının tümüyle ve gençlik yıllarının kısmen kendi hayatından (otobiyografik); olgunluk yıllarının hayal gücünden (kurmaca) beslendiği iddia edilebilir.

"İşte rüyası hayallerimde kalan Çengelköy! / Elli yıl önceki tipler işte!" (Orhon, 1970: 107) diyen 1890/Çengelköy doğumlu Orhan Seyfi Orhon'un Çocuk Adam adlı romanı ilk defa 1941'de yayınlanır. "Elli yıl" öncesinin insanlarının seyredildiği bu dizelerle kitabın yayımlandığı yılların örtüşmesi iki eserin yaklaşık aynı tarihlerde kaleme alındığını düşündürür. Bu bölümde gösterileceği üzere, "Çengelköy" şiiri ile Çocuk Adam romanı arasında içeriksel ortaklıklar/ benzerlikler oldukça fazladır. Her ikisi de sanatçının kendi yaşamına dayanan bu eserler, sahip oldukları otobiyografik özellikler nedeniyle benzer olay ve durumları anlatırlar. Bu bölümde, Orhon'un anlattığı kişi ve olayların ne kadarının gerçek hayattan alınmış olduğu sorusuyla beraber, sanatçının kendi yaşamını ne oranda kurgulayarak anlatmayı seçtiğine odaklanacağı. Kültürel hafızanın kişiye ve tekile indirgenirken eşsiz bir deneyim olarak sunulmasını sağlayan nostaljinin edebi metne etkileri ilerleyen bölümlerde ele alınacaktır.

Ancak devam etmeden önce, roman sanatının içeriksel ve kurgusal imkânlarının şiir sanatına kıyasla yazara sunduğu avantajlara kısa bir parantez açmak gerekir. Şiir, başat olarak dile dayanması nedeniyle estetiğini dilsel alanda kuran bir anlatı biçimidir. Bu nedenle, bir şiirde şairin ne anlattığı, şiirin içeriğinin, konusunun ne olduğu gibi sorular şiir dilinin, dille kurulan imgele-

\footnotetext{
${ }^{1}$ Roman 1965'te Rek-Tur Yayınları ve 2009'da Everest Yayınları tarafından yeniden basılmıştır. Orhan Seyfi Orhon, 1965'teki ikinci basımda kitabın üçüncü bölümünü tümüyle değiştirmiştir. Orhan Seyfi Orhon'un ikinci baskıya yazdığı ön sözde, "“Çocuk Adam' bir oto-biyografi değildir. Fakat bu kitaptaki 'Çocuk Adam' birçok taraflariyle benim ve bu kitaptaki her şey benim hayatımdan bir parçadır. Burada ne varsa hepsini ben yaşadım." denen 1965 tarihli kitabın, bu incelemede amaçlanan türden bir 'yeniden kurgulama' olarak görülebileceği iddia edilebilir. Burada bütün baskılar dikkate alınmakla birlikte, aksi belirtilmedikçe bütün alıntılar Semih Lûtfi Kitabevi'nin 1941 tarihli ilk baskısından yapılacaktır.
} 
rin, alışılmamış bağdaştırmaların çok gerisinden gelir. İlhan Berk'in kendi şiir dünyasından ve şiir anlayışından bahsederken dile getirdiği gibi şiirde "anlam her şey değildir" (2019: 53). Oysa, ilk modern roman kabul edilen Don Kişot'tan (1605) bu yana, romanda olay örgüsü ve bu olay örgüsünü çeşitli kurgusal tekniklerle ortaya çıkardı̆̆ı hikâye öneminden az şey kaybetmiştir. 20'nci yüzyılın başından itibaren Virginia Woolf, James Joyce gibi bilinç akışı tekniğini kullanan modernist yazarlar olay örgüsünün etkisini ilk güçlü darbeyi vurmuşlardır. 1950'lerde Fransa'da gelişen Yeni Roman, romanda olayın ve karakterin rolünü asgari düzeye çekmiştir. 1960'larda bu birikimden faydalanan postmodernizm akımı biçimsel/deneysel metinler ortaya koymuştur (Emre, 2006: 165-170, 184-188). Ancak denebilir ki edebiyattaki tüm bu avangart gelişmelere rağmen bugün klasik/geleneksel okur, romandan kendini içine alacak, sürükleyici bir hikâye sunmasını beklemeye devam etmektedir. Kaldı ki, modernizm ve postmodernizmin Avrupa ve Amerika'ya kıyasla oldukça geç benimsendiği Türk edebiyatında 1940’l1 yıllar boyunca hemen tümüyle hikâyeye (entrika, aşk vb.) yaslanan romanların (örn. popüler aşk romanları, köy romanları) altın çağını yaşadığı hesaba katılırsa, en azından bir kısmı kendi hayatından kesitlere dayanan bir hikâye anlatmak isteyen Orhon Seyfi Orhon için roman türünden daha iyi bir seçenek olmadı̆̆ 1 ortadadır.

İsimsiz başkarakterin aynı zamanda anlatıcı görevini üstlendiği Çocuk Adam üç bölümden oluşur. Birinci bölümde, bu çalışmanın odak noktasını oluşturacak olan çocukluk hatıralarına yer verilir. Anlatıcının yer yer doğrudan okura seslendiği ve okuru çocukluk günlerinin neşeli ve tasasız günlerine davet ettiği bu sayfalar romanın en coşkulu ve gerek estetik gerek kurgusal açıdan en başarılı bölümünü oluşturur. Okura yoğun bir katharsis ve özdeşleşme imkânı sunan çocukluk yıllarının bu lirik anlatısı, eski İstanbul'un huzurlu ve yeknesak mahalle yaşantısından canlı manzaralar sunar. Samimi ve sıcak bir dille aktarılan çocukluk yılları okurun hayalinde renkli ve ilginç sahnelerle canlandırılır. Her büyüğün, kendi çocukları dışında komşusunun çocuklarını da koruyup gözettiği, münasebetsizlik ettiklerinde azarladığı ve hatta dövdüğü (Orhon, 1941: 9) bu modern öncesi ve cemaat usulü yaşantıda, her türlü kısıtlamalar ve yoksunluklar bizzat çocuğun dünyasını zenginleştiren unsurlardır. Örneğin, anlatıcının "eski bir Türk evi" olarak tarif ettiği evin hissesinin yarısının sahibi Büyük Hanım ayva ağacına el sürdürmez. O ölünce anlatıcı, "bir mirasa konmanın bütün lezzetini ancak bu ayva ă̆acında tattım" der (1941: 11). Ağaçlardan toplanan meyveler, soba başında oynanan oyunlar, komşu mahallenin çocuklarıyla yapılan kavgalar, dededen dinlenen masallar gibi dönemin pek çok okurunun kendi çocukluğundan aşina olduğu durumlar Orhon'un anılarında bireysel duyular ve duygulanımlarla anlatılır. 
Edebiyat ansiklopedilerinde ve monografilerde Orhan Seyfi Orhon'un hayatı hakkında verilen bilgilerin, kitabın çocukluk anılarından oluşan birinci kısmında anlatılan olaylarla büyük oranda uyumlu olduğu görülür. Kaynaklardan asker bir babanın oğlu olduğunu öğrendiğimiz Orhon, ilköğrenimine Çengelköy Mekteb-i İbtidâisi'nde başlar, orta öğrenimine Beylerbeyi Rüşdiyesi'nde 1905'e kadar devam eder. Mercan İdâdîsi'nden 1909'da mezun olur. Kısa bir süre mülkiye ve tıp mekteplerinde öğrenim görür, ancak bir ameliyat sırasında bir hastaya yapılan anestezi yapılırken fenalaştı̆̆ından (Yalçın, 2010: 783) tıp mektebini terk eder ve Mekteb-i Hukuk'a girer ve buradan 1914'te mezun olur. İlk mesleğine Meclis-i Mebusan Kavânin ve İçtimaât-1 Umumiye kâtibi olarak başlar.

Orhon'un biyografisinin buraya kadar olan kısmı Çocuk Adam'da aynen aktarılır. Romanda sert ve disiplini bir asker baba vardır ve aldığı terfilerle miralaylığa kadar (1941: 60) yükselir. Anlatıcının devam ettiği okulların adları çoğunlukla verilmez ancak bunun bir istisnası olan Beylerbeyi Rüşdiyesi "yarı mektep, yarı medrese bir yer" (1941: 42) olarak betimlenir. Babasının kaymakam olarak çalışmaya başladığı günlerde idadiye girdiğini (1941: 46) nakleden anlatıcı, buradan mezun olduktan sonra doğruca Mekteb-i Hukuk'a geçer. Orhon'un mülkiye ve tıp mekteplerindeki kısa dönemlerine değinmediği dikkati çeker. Yukarıda andığımız tıp mektebinden ayrılmasına neden olan tatsız olay, bütün otobiyografilerde olduğu gibi yazarın hatıralarını kullanırken belli bir seçim yaptığının kanıtı olarak kabul edilebilir.

Kahraman'ın, Orhan Seyfi Orhon'un "1920'ye kadarki hayatını anı-roman tarzında” (2007: 390) anlattığını belirttiği Çocuk Adam kesin bir çizgiyle ayırmak mümkün olmamakla birlikte ikinci bölümden itibaren tarihsel/otobiyografik bir metin olmaktan çıkar. Orhon'un anılarından çıktığımızı düşünmemizin nedeni, romanda -hele ki bu, bir Cumhuriyet bürokratı, aydını ve sanatçısının romanıysa- birçok insanın itiraf etmeye cesaret edemeyeceği bir dizi olaya yer verilmeye başlamasıdır. Bu bakımdan, otobiyografi türünün önemli bir biçimi olan itirafnamelerin (örn. Jean Jacques Rousseau-İtiraflar, 1782) tonunu fazlasıyla hatırlatan bu bölümlerin otobiyografik alanı terk ettiğimizi haber vermesi kuvvetle muhtemeldir. Örneğin, Mekteb-i Hukuk'tan mezun olan anlatıcı bir süre işsiz gezdikten sonra çalışmaya başlaması konusunda yapılan baskılara daha fazla direnemeyerek bazı kalemlere iş başvurusunda bulunur. Meclis-i Mebusan Kavânin ve İçtimaât-1 Umumiye'de kâtip olarak girmesini sağlayacak gerekli "iltimas" sağlanır ve geriye usulen girilmesi gereken bir sınav kalır. Anlatıcı, kazananın çok önceden belli olduğu ve "imtihan komedyası" olarak adlandırdı ğı bu sınavın sonrasinda şu itirafta bulunur: "Bu imtihan bana hem gülünç, hem hazin geldi. Yirmi kişi kadardık. İçlerinde müsabakayı mutlaka kazandığına inananlar vardı." (1941: 90). 
Burada Orhon'un romanında var olduğu öne sürülen kurmaca-d1şı/kurmaca arasındaki sınır, romanın aksamasına neden olduğu görülen en önemli kusurlarından biriyle de doğrulanır. Bu, yazının sonraki bölümünde Bildungsroman türüne girdiği örneklerle gösterilen romanın başkarakterinin gelişiminde izlenen tutarsızlıktır. Çocukluk ve gençlik yıllarında son derece duyarlı ve çekinden bir yapıya sahip olduğunu görülen Çocuk Adam'ın anlatıcısı, daha sonra gösterileceği gibi, olgunluk yıllarıyla beraber Lolita'nın (1955) küçük ve baştan çıkarıcı kızlara meyilli başkarakteri Humbert Humbert'in ikizine dönüşür. Bununla birlikte, romanın ilk iki bölümündeki otobiyografik içerik nedeniyle üçüncü bölümün de gerçek olaylar içerme ihtimalini düşündürmüş olmalıdır ki, Orhon'un, romanın 1965'teki yeniden baskısında yaşlı bir adamın cinsel tutku ve hezeyanlarını anlatan üçüncü bölümü tümüyle çıkararak yeniden yazdığı görülür. Romanın, 1965 tarihli baskısında, üçüncü bölümde orduya yazılma kararı alan anlatıcının askerlik maceralarına, ardından cephe gerisine alınarak Ordu Mecmuası'ndaki ve en son levâzım ikinci şubedeki mesaisi anlatılır. Orhon'un, yaşlı bir adamın çapkınlık ve sefahat maceralarını eserinden çıkararak genç ve vatansever bir askerin hikâyesine dönüştürmesinde dönemin okur kitlesinin eseri alımlama şeklinin etkili olduğu düşünülebilir. Metin odaklı okuma alışkanlığı düşük bir profil çizen dönemin okur kitlesi, Orhon'un "Bu kitabı karıma ithaf ediyorum. Bu satırlar onun zeki tenkitleriyle, samimî teşvikleriyle meydana gelebildi. Ben, burada, bütün hayatımı dolduran teşekkür ve minnettarlıklarımı ödemeğe çalışıyorum." (Orhon, 1941: 3) sözleriyle karısına ithaf ettiği kitapta anlatılan kadın-erkek ilişkilerini epey yadırgamış olmalıdır. ${ }^{2}$

\section{Bir bildungsroman ve künstlerroman olarak Çocuk Adam}

Batı Edebiyatında geniş bir külliyat oluşturan Bildungsroman (yetişme çağı romanı) ile Künstlerroman (sanatçı romanı) Türk edebiyatında, özellikle de modern Türk edebiyatının erken yıllarında, eşit derecede benimsenmiş türler değildir. Bir genelleme yapmak gerekirse, edebiyatın daha çok yüksek ve estetik mecrasını beslediği görülen bu türlerin (örn. Buddenbrook Ailesi (1901), Martin Eden (1909), Sanatçının Bir Genç Adam Olarak Portresi (1916)) Türk edebiyatında postmodernist eğilimlerle birlikte yükselişe geçtiği dikkat çeker. Buna rağmen, başlangıcından itibaren Türk edebiyatında bir kişinin veya bir sanatçının geçirdiği değişim evreleriyle birlikte bütün hayatını işleyen az sayıda eser, Türk

\footnotetext{
${ }^{2}$ Orhon, kitabın 1965 tarihli yeniden yazılmış versiyonunun ön sözünde bugün bile edebiyatseverler için oldukça garip ve şüpheli görünebilecek şu açıklamayı yapar: "Bu romandaki tiplerin birçoğu, gerçek hayattakilere uyar. Böyle bir baba, bir anne, bir büyük anne, bir kardeş ve bir büyük baba vardır. Hepimizin üzerinde en derin iz bırakan bu sonuncusudur. Bă̆ ve bağdaki hayat doğrudur. Ilk çocukluk aşkl, ondan sonra ilk gençlik macerası, başka yerlerden alınmış motiflerle biraz süslenmiştir. Amca da doğrudur. Fakat amcamın kızıyle mâcera, sâdece bir taraflı, benim içimde yaşanmış bir maceradır. Bu kitabın birinci ta'bı aceleye gelmişti. Üçüncü kısmı yazılmadan dizilmeğe başlanmıştı. Asıl 'Çocuk Adam' budur. Sonradan bu üçüncü kısmı tamamladım." (Orhon, 1965: 4-5).
} 
edebiyatının klasikleri arasında kabul edilen romanlardır. Ahmet Mithat'ın Felâtun Bey ile Râkım Efendi (1875), Müşâhedât (1891), Halit Ziya Uşaklıgil'in Mâi ve Siyah (1897) ve Recâizâde Mahmut Ekrem'in Araba Sevdası (1898) romanları Türk edebiyatında bu türlerin ilk ve en önemli örnekleri arasındadır (Parla, 2011: 10).

Kendinden önceki bu edebi birikimden faydalanan Orhan Seyfi Orhon'un, Çocuk Adam'da bu iki türü melezleyen bir eser ortaya çıkardı̆̆ı görülür. Daha önce belirtildiği gibi, romanın birinci bölümü başkarakterin çocukluk yıllarının anlatımıyla başlar, simgesel bir anlam yüklenen çocukluk evinden taşınmayla sona erer. Roman ikinci bölümde ağırlıklı olarak gençlik yıllarına ve bu yıllarda yaşanan gönül ilişkilerine ayrılır. Çocukluk yıllarının masum ilgileri genç karakterin tutkulu aşklarına evrilir. Yaşanan gönül ve hayal kırıklıkları romanın ikinci kısmına genel havasını verir. İkinci bölümün sonunda, genç karakterde büyük sarsıntıya yol açan bir gönül macerasının ardından (pek çok gençlik anlatısında olduğu gibi) orduya katılma kararı alınır. Bir arınma ve uzaklaşma arayışıyla orduya katılan anlatıcı üçüncü bölümde artık orta yaşlı ve olgun bir erkek olarak okurun karşısına çıkar. Anlatıcının gençlik yıllarından arkadaşı Cemal Nahit'e yirmi üç senelik bir ayrılığın ardından yazmaya başladığı mektuplarından oluşan bu son bölümde anlatıcı aradan geçen yıllarda yaşadıkları hakkında bilgiler verilir. Anlatıcı, gençlik yıllarındaki en büyük aşkı olan amcası (aslında "Hacı babamın kardeşinin oğlu" (1941: 62-63) Halit Bey'in kızı Malike'yle on sekiz yıldır evlidir. Çiğdem adında evlatlık kızlarıyla aynı evde mutlu bir aile hayatı sürerler. Anlatıcının yeni açılan Esnaf Sigorta Şirketi müdürlüğüne terfi olmasının ardından gelişen olaylar bu bölümün olay örgüsünü ve bütün romanın temel entrikasını oluşturur. Başkarakterin çocukluk ve gençlik yıllarını geriye dönük bir bakışla aktarıldığı ilk iki bölümün ardından anlatı zamanıyla anlatma zamanı arasındaki fark en aza iner; hatta bölümün sonunda anlatıcının başına gelen felaketi anlattığı mektupta bu iki zaman tümüyle örtüşerek iç içe geçer. Böylece çocukluğundan başlayarak olgun bir erkeğe dönüşen anlatıcının dönüşüm-gelişim hikâyesi tamamlanmış olur. Çocuk Adam, hikâyesinin başlangıcı ve tamamlanışı bakımından bir karakterin bir noktadan başlayarak hayat tarihini okura sunan Bildungsroman' in genel hatlarına uyar. Anlatıcının inişlerini, çıkışlarını, hayatındaki dönüm noktalarını anlatan romanda, Bildungsroman geleneğine uygun olarak romanda "Insan, hiçbir zaman bir kişi değ ildir. Birbirinden büsbütün ayr birçok şahıslardan mürekkep bir âlemdir." (Orhon, 1941: 106) denir.

Anlatıcının yetişme hikâyesini anlattığını gördüğümüz Çocuk Adam, aynı zamanda bir sanatçı romanıdır. Dünya ve Türk edebiyatlarından verdiğimiz örneklerdeki roman karakterleri gibi tipik sanatçı özellikleri göstermese de 
anlatıcının küçük yaşından başlayarak şiir yazıp okuduğu görülür. Duyarlı, romantik ve içe kapanık bir çocuk olduğu gözlenen anlatıcı karşı cinsle olan ilişkilerinde olduğu kadar sosyal ilişkilerinde de sorunlar yaşar. En sevdiği ders kıraattir. Dönemin önemli dergilerinden İktitaf taki şiirlere nazireler yazar. Karşı cinse yönelik güçlü duygular onun "hevesi(n)i asıl körükliyen" (1941: 44) etken olur. Genç adamın yaşadığı en fırtınalı aşk macerasında Nezahet adlı kadın için pencere kenarlarında şiirler okur (1941: 103). Ancak başkarakterinin duygusal derinliği ve entelektüel birikimi bakımından yukarıda örnekleri verilen Künstlerroman türünün önemli romanlarına denk tutulamayacak Çocuk Adam'ın bir sanatçı romanı kabul edilmesini gerektiren son ve en güçlü neden, anlatıcının mektup arkadaşı Cemal Nahit'e şu vaadidir: "Belki boş zamanlarımda bütün hayatımı yazıp sana gönderirim. Beni o zaman daha iyi tanırsın. Nasıl bir muhit içinde büyüdüm? Niçin böyleyim? Belki acırsın, belki de... Hayır, hayır, karşılık istemem! Sana benim bu bir hediyem olsun!" (1941: 174). Okurun elinde tuttuğu kitap, anlatıcının dostuna yazmayı vadettiği romandır. Böylelikle, metakurmaca tekniğiyle verilen sözün tutulduğu, eyleyenini sanatçı yapmaya yetip yetmeyeceği tartışmalı da olsa bir sanatsal üretim sonucunda hikâyenin veya daha özgül olarak "Niçin böyleyim?" sorusuna cevap veren otobiyografinin tamamlandığı anlaşılır. Şu hâlde birbiriyle uyum içinde olabilecekken rekabete, çatışmaya itilen iki model, iki format belirir: biri saygınca ve masumca edebî (yetişme romanı), diğeri acemice teorik (sanatçı romanı). Bu iki temsil tarzı Çocuk Adam'da önce dostane, karşılıklı destekleyici, ama sonra giderek huzursuz, kısır bir alışveriş içine girerler. Geri dönüş, hatıra defteri, mektup gibi edebi teknik ve türlerin kullanıldığı romanda görülen biçimsel dağınıklık kadar romanın iç tutarlığını zedeleyen yapısının, Çocuk Adam'ın yukarıda adları verilen Türk ve dünya edebiyatlarından son derece başarılı örnekler arasına girmesini engellediğini Bildungsroman-Künstlerroman parantezini kapatırken kaydedelim.

\section{Çocuk kalmak ile adam olmak arasında: Çocuk adamlık}

Aksoy, "Kendi hayatın yazan bir kimse, hayatının hikâyesini nesnel bir biçimde anlatabileceğine, hayatının hakikatini kamuoyu ile paylaşması gerektiŏine, böylece hayat bilgisini metinleştirebileceğine inanan bir kişidir." (2014: 14) derken aynı zamanda otobiyografi yazarının eserinde zorunlu veya istemli bir seçmece yaptığını ima eder. Bir otobiyografi olmadığı anlaşılan ancak yoğun biyografik içeriğiyle dikkat çeken romanında Orhon, anılarını Aksoy'un sözünü ettiği türden bir seçmeceden geçirirken bazı konularda oldukça açık sözlü davranır. Daha önce değinilen anlatıcının memuriyet hayatına adım atarken başvurduğu usulsüzlük kadar kadınlarla olan ilişkileri de samimiyetle sergilenir. Romanda Bildungsroman-Künstlerroman türlerinin örneklerinde sıkça öne çıkan cinsellik konusu burada da geniş bir yer tutar. Anlatıcı, iptidai günlerinden başlayarak 
eğitim hayatı boyunca karşı cinse duyduğu ilgiyi paylaşır. Mekteb-i Hukuk'a devam ettiği sırada Nezahet adlı komşu kızıyla sonu hüsranla bitecek bir gönü macerasinı anlatir.

Daha önce belirtildiği gibi, kurmaca düzleme geçildiğini düşündüren sayfalarda anlatıcı, amcasının kızı Malike'yle mutlu bir evlilik gerçekleştirir. Malike'nin hayatına tekrar girmesiyle anlatıcı, özgüvenini ve "şahsiyeti" ni kazanır: "Tereddütlerimle, iradesizliklerimle, bir türlü gizleyemediğim teessürlerimle, çarçabuk parlayan arzularımla, hayalperestliklerimle, manâsız saadetlerim veya bedbahtlıklarımla daima bir çocuk adam kalacaktım." Bu itirafın devamında, kitaba ismini veren "çocuk adam" oksimoronunun "mütemadî inkisarlara uğriyarak kendi nefsiyle didişmeden başka bir işe yaramıyan bir insan" (Orhon, 1941: 121) şeklinde tanımlandığı görülür. Orhon, tıpkı Oğuz Atay'ın ünlü "Biz çocuk kalmış bir milletiz" (2007: 24) yargısının bir yönüyle ifade ettiği gibi, çocukluğu olumsuz anlamda, 'ergin olma', 'olgunlaşma', 'akıl ve mantıkla hareket etme' hallerinin karşıtı olarak kullanır (İmgeleri sıklıkla çok katmanlı ve karşıtıyla beraber düşünen Atay'ın 'çocuk kalma'yı aynı zamanda 'toplumsal olarak bozulmama' olarak değerlendirdiğini not düşelim). "Çocuk adam” bir tür beceriksizlik, sakillik ve toyluk hâlidir. Oysa anlatıcı ergen değil, ergindir artık. Deneyim sahibidir. Malike'yle sürdürdüğü on sekiz yıllık mutlu evlilik hayatı bunu gösterir. Anlatıc1, kendini tanıma ve tümüyle idrak etme noktasındadır. Çocuk Adam, yayınlandığında büyük tartışmalar kopartan Lolita'dan on dört yıl önce çıkar. Ancak daha önce de belirttiğimiz gibi, anlatıcının itiraflarında Lolita'nın yaşı geçkin ve sefih âşığı Humbert Humbert'in birçok insan için son derece rahatsız edici olabilecek saplantılarını, nevrozlarını bulmak mümkündür:

"Malike'yle on sekiz seneden beri evliyiz. Tahmin edersin ki artık bizim için ihtirash bir aşk olamaz. (...) Hiç şüphesiz karımı eskisinden daha çok seviyorum. Fakat bu benim ufak tefek çapkınliklarıma mâni olmuyor. Utanılacak bir tarafim var, itiraf etmeliyim: Küçük kızlardan hoşlanıyorum. Bu zâf bana nereden geldi bilmem? Gittikçe yaşlanıyorum da ondan mı? Yoksa Nezahet'in içimde bıraktığı bir dert mi? İhtiraslarımda âdeta bir âşık (Landrü) gizli. Hoşlandığım kızlar, on altı, on yedi, on sekiz yaşlarında yarı fahişe bakirelerdir." (1941: 122).

Mektup arkadaşı Cemal Nahit'e bunları yazan "Çocuk Adam", Esnaf Sigorta Şirketi'ndeki görevine başladıktan sonra yarı-zamanlı iş başvurusu yapan Neriman adlı on yedi yaşında bir daktilo kızı yanına alır. Müdürlükte boş kadro bulunmadığı için anlatıcı, Neriman'ı maaşı kendisi tarafından ödenmek üzere 30 lira aylıkla işe kabul eder. Mektubunda bunları anlattıktan sonra arkadaşını kendisine güvenmesi konusunda temin eder: "Hiçbir tehlike yok. Ne onun bana âşık olma ihtimali var, ne benim! Bu çağları çoktan geçtim." (1941: 132) Birkaç mektup sonra işin seyri kısa sürede değişir ve anlatıcı için Neriman bir obsesyon 
haline gelir: "Neriman'la münasebetimiz çı̆̆rından çıktı. Onu, hafif neş'e veren bir içki gibi yudum yudum tatmıya çalışacă̆ım yerde birdenbire alkolik bir adam oluverdim." (1941: 139).

Neriman kısa zamanda anlatıcı için tutkulu bir arzu nesnesine dönüşür. Müdürlüğün daireleri içinde kavgalar, rezaletler alıp yürür. Anlatıcının "Nezahet'in içimde bıraktı̆̆ı dert" dediği cinsel açlık, Çocuk Adam'ın psikanalitik bir Bildungsroman olarak değerlendirilmesini mümkün kılar. Lacan'c1 teori nevrozun iki temel türü arasındaki böyle psikolojik farklılıkları yapısal bir karşıtlık şeması içine yerleştirir: cinselliğin ilk hissedilişine verilen farklı cevaplar. Histerik (sonradan histerik olarak belirecek kişi) cinselliği dışarıdan gelen tatsız bir şey olarak şiddetle hisseder ve rahatsız olur. Obsesif ise yine dişarıdan gelen bir şey olarak şiddetle hissettiği erken cinsellikten fazla tat alır. Bu, baş edilemeyecek kadar fazla, suçlu bir haz, suçluluğu başlatan hazdır. Bu noktada, psikanaliz çözümlemeler devreye girer; Freud'un vaka analizlerinde büyük önem verdiği “çocukluk dönemi cinselliği”" (1996: 37) etkin olur. Müstakbel histerik, ötekinin arzusuna oynamayı seçer. Kendisi tam kapılmaksızın ötekinin arzusunun nesnesi olmayı (ama hazzının nesnesi değil -bu, sapığın seçimidir) ve o arzuyu hep canlı tutmayı yeğler. Müstakbel obsesif ise geri kalan hayatını o ilk aşırı hazdan kaçınmaya adar, onu çeşitli yöntemlerle seyreltmeye çalışır. Bütünden çok parçalara odaklanmaya, bütünü ufaltmaya, çözmeye, analiz etmeye gayret eder. Histerik hep karşı tarafın arzusunu kışkırtıyorsa eğer, obsesif herhangi bir "karşı taraf” figürünü (özellikle de canlı ve talepkâr bir öteki'yi) silmeye yönelir. Freud'un "Sıçan Adam” vakasının çözümünde vurguladığ1 gibi, obsesifin memnuniyeti daha ziyade "mastürbatif"tir, canlı ve talepkâr (ne isteyeceği belirsiz) bir karşı tarafla muhatap olmak yerine, kendi hayal gücünün emrine girer (Freud, 1996: 70-85). Öte yandan burada nesneye ilişkin bir ayrışma da olmuştur, seksle aşk veya 'realizm' ile 'romantizm/idealizm' arasında: bir yanda 'yarı fahişe', öte yanda 'bakire' (veya 'daktilo kız').

Anlatıcının müdürlük dairesinde Neriman'la saç saça baş başa kavgasının ardından yaşanan rezalet üstü örtülecek gibi değildir. Bu nedenle, anlatıcı derhal istifasını vererek daireden ayrılır. Bir gününü otelde geçirir. Karısından af dilemeye karar verir. Ancak eve geldiğinde kimseyi bulamaz. Malike'nin biraktığ1 mektuptan her şeyi öğrendiğini ve kendisini ebediyen terk ettiğini anlar. Anlatıcı, darmadağınık eşya arasındaki aynaya baktığında tükenmiş bir adam görür. Ancak aynada asıl gördüğ̈ü sefil "ego"su değil, hınç ve öfke dolu "id"i 'çocuk ben'idir. Anlatıcı, ona bakarak ikinci kez çocukluğuna döner:

"Ben işte, bu bağları, bu mukaddes bağları gevşetmiye, koparmıya çalışan bir aptalım! Çocukluğumdan beri aile nizamına, an'aneye karşı geldim. Ne bekliyordum acaba? Hür yaşamak, mes'ut olmak mı? Insan ruhu, hürriyetin tadını 
ancak onun sinırları içinde duyabiliyor. (...) Neden içimdeki fena hevesleri bu kadar başıboş bıraktım?" (Orhon, 1941: 162)

Bu trajik sahnede oldukça ilginç bir durum ortaya çıkar. Beklenmedik, şüpheli bir itiraf gelir. Kitabın birinci bölümünde okurla paylaşılan çocukluk yılları hakkında ilk defa dile getirilen ve romanda bu noktaya kadar anlatılan çocukluğa dair söylenenler içinde eğreti duran bir gerçek ifşa edilir. Bu, anlatıcının en erken anılarından oluşan kitabın birinci bölümünü özetlerken belirttiğimiz gibi huzurlu ve âsude geçtiğini söylenen çocukluk tarihinin yeniden yazılmasına ve yeniden kurgulanmasına yol açacak şaşırtıcı bir itiraftır. Okur, anlatıcının güçlü bir nostalji duygusu ve şefkatle yaklaştığ1 'çocuk ben'in amansız bir toplum düşmanı ve düzen karşıtı olduğunu öğrenir. Bu durumda kendiliğinden bir soru işareti belirir dikkatli okurun kafasında: Bu çocukluk tarihine ait iki farklı versiyondan hangisi doğrudur?

\section{Cumhuriyet aydınından Osmanlı çocuğuna nostaljik bir bakış}

Her otobiyografi yaşananlar arasında belli bir seçmeyi gerektirdiği kadar her seçilen belli bir yorumu gerektirir. Bellek, bilinçdışı, çağrışımlar, savunma mekanizmaları kadar geri çağırma/hatırlama ediminin kendisinin de devreye girdiği bu süreç nostaljiye içkin bir illüzyonu beraberinde getirir. Bu yazıda 'nostaljik yanılsama' olarak anacağımız bu durum, hatırlanan olay ve kişileri 'sahte anı'lardan oluşan bir hâle içinde görmenin bir sonucudur. İlk kez Peter J. Freyd'in ortaya attığı "sahte anı sendromu" (false memory syndrome veya FMS) (McHugh, 2008: 55) kişinin kimliğini ve başkalarıyla ilişkilerini etkileyen, aslında yanlış olduğu halde doğruluğuna kuvvetle inandığı psikiyatrik bir durumdur. Uzmanlar tarafından hastalık olarak değerlendirilmeyen sahte anı sendromu, bilim adamlarının, anıların dış etkenlere bağlı olarak değişebileceği ve çarpitmaya uğrayabileceği tezini kuvvetlendirir (Schachter, 2002: 34).

Çocuk Adam'ın ilk bölümünde minnet ve özlem dolu bir nostalji duygusuyla hatırlanan çocukluk yıllarının, kitabın ilerleyen bölümlerinde ilk günah tohumunun atıldığı mümbit bir arazi olarak hatırlanması, araştırma konusunu psikoloji biliminin alanına doğru iter. Bilim adamları arasında yaygın biçimde destek bulan anıların dış etkenlere bağlı olarak değişebileceği düşüncesi kabul edilecek olursa bu defa da söz konusu edebi soruna sosyolojik bir açıklama getirilmesi gerekir. Bu vakada, her iki alandan gelecek olgusal analizlerin tespit edilen probleme çözüm sunabileceği düşünülebilir.

Osmanlı'nın son döneminde dünyaya gelen Orhan Seyfi Orhon, Cumhuriyet'in yetiştirdiği ilk aydın kesim olarak kabul edilebilecek kuşağın bir üyesidir. Babıâli'nin en popüler gazetelerinde çalışmış, dergiler çıkarmış, Türk ede- 
biyatının en önemli edebi hareketlerinden birinde yer almış bir edebiyatçı ve milletvekilliğine kadar devletin çeşitli kademelerinde görev yapmış bir bürokrattır. Orhon'un da içinde bulunduğu Cumhuriyet'in ilk yetişmiş kuşağı say1labilecek bürokrat-yazar-aydın zümre, çocukluk yıllarını Osmanlı Devleti'nin son yıllarında yaşanan 'beka kaygısı' nedeniyle derin bir travmanın etkileriyle geçirmiş, gençlik yıllarına denk gelen Cumhuriyet'in ilanıyla bir özgüven patlaması yaşamıştır. Erken Cumhuriyet döneminin başta gelen bürokrat-aydın yazarlarından biri olan Yakup Kadri, Atatürk adlı eserinde bu durumu, "Bizim ilk gençlik yıllarımız bir milli kahramana hasretle geçti. Biz-şimdi ellisine varanlar, ellisinden ötedekiler- gözlerimizi bozgun havası içinde açtıktı." (2014: 17) sözleriyle ifade eder. Cumhuriyet'in ilanıyla kendisine modernleştirici bir misyon biçen entelijansiya Osmanlı'nın 'hasta adam' imgesi etrafında şekillenen aşağılık komplekslerini geride birakarak modern ve akılcı yeni rejimin değerlerine sıkı sıkı tutunur. Bu nedenle, Cumhuriyet'in ilk kuşağının karanlık bir heyula olarak gördüğü Osmanlı mazisine çoğunlukla dönüp bakmayı tercih etmez. Baktığında da ya bir hesaplaşma içindedir ya da geçmişi kötüler. Erken Cumhuriyet döneminin önemli ideologlarından Mahmut Esat Bozkurt'un Anadolu İhtilâli (1967) ve Recep Peker'in Inkılap Dersleri (1936) kitapları bu konuda akla gelen örneklerdir. Resmi ideolojiyi gerek edebi gerek edebiyat dişı alanda yaymayı üzerine alan bu kuşak, genel anlamda gelecekle, daha açık bir ifadeyle, ulus-devletin istikbaliyle ilgilidir. Milli Edebiyat mensupları aynı dönemde modernleşme projesinin adım adım başarıya ulaştığını görmenin kıvancıyla ve hâlen hayatta olan lider kültünün cesaretlendirmesiyle ulusal coşku ve özgüveni ortaya koyan eserler üretirler.

Ancak Mustafa Kemal'in ölümünün ardından ulusal coşkuda bir sönümleme baş gösterir. "Baba figürü" olarak görülen Mustafa Kemal'in ölümüyle beraber, rejimin ilkelerinden, devrimin ruhundan giderek uzaklaşıldı̆̆ını hisseden Cumhuriyet aydınları bir süredir ilgilenmedikleri geçmişe dönerek bu defa yeni rejimin kendisinin muhasebesini yapmaya başlarlar. Özellikle muhalif yazarlar, Cumhuriyet ideallerinden kopmanın hangi noktada başladığını sorgulamaya başlayan hiciv ve ironi yüklü ütopyalar kaleme alırlar (örn. Halikarnas Balıkçısı-“Büyük Kukuriko” (1948)). Bu bakımdan, rejimin uyumlu sanatçılarından biri olmasına rağmen Orhon'un Çocuk Adam romanı da Cumhuriyet'in ilk yıllarına retrospektif bir bakış yönelten eserler halkasının ilk örneklerinden biri olarak değerlendirilmelidir. Nişanyan Sözlük'te "nostalji" sözcüğünün ilk defa 1931 tarihli bir Cumhuriyet gazetesi nüshasında geçtiği kaydedilir (Nişanyan, 2010: 451). ${ }^{3}$ Büyük umutlar beslenen Cumhuriyet proje-

${ }^{3}$ Basılı sözlükte "nostalji" sözcüğü için Mustafa Nihat Özön'ün Türkçe-Yabancı Kökenli Kelimeler Sözlü̈̆̈ü (1961) kaynak gösterilirken çevrimiçi sözlükte 1931 tarihli Cumhuriyet gazetesindeki kullanım örnek gösterilir. Cümle şöyledir: “...derin bir tahassürle, adeta bir nostalji ile İstanbul'u düşünür.” (Nişanyan sözlük, t.y.). 
sinin ilk başarısızlık sinyallerini vermesinin ardından, "nostalji" sözcüğü Türk entelijansiyasının lügatindeki yerini pekiştirir. Cumhuriyet aydınlarına "dünya düzeneğindeki tam çaresizlik ve önemsizliklerini" (Freud, 2000: 44) iyiden iyiye hissettiren modernleşme sınavındaki başarısızlık, onları sorunun kaynağı olarak gördükleri çocukluklarının evine, Osmanlı mazisine geri dönüp bakmaya iter. Bir enkaz olarak görülen Osmanlı bakiyesinin kalıntıları arasında modernleşme projesinin aksayan yönlerinin kaynakları aranır. Cumhuriyet aydınının genetik kusurlarının kökenleri, kendi kişisel gelişimlerinin başlangıcına tekabül eden çocukluk yıllarına, yani Osmanlı'nın son yıllarında tespit edilir.

Orhon, Çocuk Adam'da çocukluğuna iki kez döner. Böylece, anlatıcıya yüklediği kendi çocukluğuna ait hatıralarını iki kez hatırlamış olur. İlk hatırlama, daha önce belirtildiği gibi, çocukluğu bir rüya estetiğine yakın bir üslupla sunar. Anlatıcı, bağ evine gittiği zamanları, "O zaman sahiden çocuk olurdum" (Orhon, 1941: 18) diye anarken çocukluğu bir anlamda mutlulukla eşitler. Bu, Tarancı'nın kendi çocukluğunun Cuma günlerini anarken, “Uzun olaydı o günler" (1983: 155) deyişindeki duygu durumunun bir benzeridir. Geçmişe özlem dolu bu hatırlama, bütün olumsuzlukların üstünü örten bir tür güzellemeyi de kuşkusuz içinde saklar. Bu bakımdan, 'nostaljik yanılsama' adı verilen süreç burada da etkindir. Ancak, burada gerçeği çarpitan ve sahte anı üreten bir süreç olarak sözünü edilen zihinsel dönüşüm, ikinci hatırlamada başat ve güçlü bir mekanizma olarak belirir. Anlatıcı, çocukluğuna bakıp orada hayatına içkin bütün kötülüklerin kaynağını görmeye başlar. Çocukluğu, Pandora'nın kutusu gibi bir defa açıldığında bir daha geri itilemeyecek günah ve suçları saçan kapalı bir kutu; adeta bir kötülük komprimesidir.

Cumhuriyet projesinin arzulanan amaçlara ulaşmaktan uzağa düştüğü gerçeğinin, Cumhuriyet'in kurucusunun ölümüyle tedrici olarak anlaşılması baba figürünün ortadan kalkmasına bağlanabilir. Ancak, yüzü ileriye dönük Cumhuriyet aydınının 1940'1 yıllardan başlayarak sık sık geriye bakması yalnızca lider kültünün şefkatli ve koruyucu nazarlarının yokluğuyla açıklamak yeterli olmayabilir. Orhon'un, dolayısıyla romanda üst düzey bir bürokrat olduğu görülen anlatıcının, işler sarpa sardığında yaptığı gibi bütün hataların kaynağını çocukluğunda bulmasında, Cumhuriyet' in aksayan işleyişindeki yapısal kusurları Osmanlı mirasına atan bir savunma mekanizması vardır. Osmanlı geçmişini tarihte karanlık bir sayfa olarak gören Cumhuriyet aydını, söz konusu hesaplaşmayı, Çocuk Adam'da örneklendiği gibi, kendi çocukluğunu dahi kriminalize etmeye kadar götürerek yapar.

Bu bakımdan, resmi tarih kaynaklarında kadınları daha önce sahip olmadıkları haklarla hiç olmadıkları kadar özgürleştirdiği ileri sürülen Cumhuriyet rejiminin en büyük mefahir tablolarından biri olan 'kadın meselesi' burada 
tartışılan geçmişle hesaplaşmayı anlamak bakımından faydalı olabilir. Hilmi Yavuz, Tanzimat ve sonrası dönemdeki modernleşme hareketinin özünün " $k a$ dın özgürlüğ̈̈" olduğunu dile getirdiği yazısında, Tanzimatçıların özel alanda eğitilmesini önerdikleri kadının Kemalist ideolojide kamusal alana taşınmasını -Şirin Tekeli'den aktararak- "devlet feminizmi" olarak değerlendirir. (2015: 7-15). Bu dönemde üst sınıf erkeklerin, Kemalist devrimlerin başarısını kadının kamusal alandaki görünümleriyle ve kendilerinin bu değişime bağlı olarak aldıkları mevziìle ölçtükleri görülür. Kadın-erkek eşitliğinden kılık kıyafet inkılabına ve yüksek sosyete hayatından "familya âdâb-ı muâşereti"ne (Muzaffer, 1942: 5-6) kadar bir dizi yeni standart erkeklerin modernleşme performansını ölçmede belirleyici olur. Kadınların metres hayatındaki görevlerinden aldatan kocaya gösterilmesi gereken müsamahanın boyutlarına kadar çoğunlukla erkek yazarlar tarafından belirlenmiş bu kurallar dizgesi dönemin popüler romanlarında kendine geniş bir takipçi kitlesi bulur. Erkeğin her anlamda kad1na karşı üstün konumu berkiten bu ahlak anlayışı 'kadının namusu', 'erkeğin vazifesi', 'et aşkı' gibi geleneksel ve ataerkil okur kitlesinin ahlak anlayışıyla uyumlu sloganlar üzerinden mesajlarını iletir.

Erken Cumhuriyet dönemi yazarlarının bu eril ahlakçılığı, onları Osmanlı döneminde verilmiş Türk edebiyatının en önemli eserleriyle hesaplaşmaya iter. Mustafa Baydar'ın, dönemin edebiyatçılarıyla yaptığı röportajlarında Orhon, Aşk-ı Memnu’ya yönelik eleştirilerini şu sözlerle savunur:

"Romancı kendi eserine mevzu olarak cemiyette gayri ahlakî telakki edilen bir hadiseyi alırsa bunu tenkit için, bu tehlikeden cemiyet( $i$ ) kurtarmak için yaptığını anlatan bir zihniyet göstermeli. (...) Aşk-ı Memnû'dan sonra Behlül ler, Bihter'ler hayatımızda çoğalmış, yükselmiş sosyeteye mensup mümtaz insanlar olarak görülmeye başlamıştır. Ben belki biraz ahlâkçı bir düşünce ile söylüyorum ama bu taraflarımızın edebiyata geçmesini, onların üzerinde üslup hünerleri, canlı tasvirler, onlarda başkaların imrendirecek cazibe bulmayı hoş görmüyorum." (Baydar, 2015: 235)

Baydar'ın 1960 tarihli röportajında, o tarihten yaklaşık yirmi yıl önce yayımlanmış ve "on altı, on yedi, on sekiz yaşlarında yarı fahişe bakireler"den hoşlanan orta yaşlı bir adamın hayat hikâyesinin anlatıldığ söz açılmaması dikkat çekicidir. Bu suskunluk için ahlaki olduğu kadar edebi nedenler de bulunabilir. Cinsel içerik bakımından Aşk-ı Memnû̀'dan fazlasıyla zengin bir roman olan Çocuk Adam'da, yaşanan gönül maceralarına ait aşk sahnelerini özlemle, Neriman adlı daktilo kızın fiziksel cazibesini orta yaşlı bir adamın arzu dolu hayıflanmalarıyla aktaran Orhon yukarıda sözünü ettiği "üslup hünerleri, canlı tasvirleri" sergilemekten uzaktır. 
Bir bütün olarak estetik ve edebi olarak üstüne çıkamadığı bir sanat düzeyini itham eden bu tavır, daha geniş çerçevede Osmanlı geçmişini hedef alır. Benzer bir refleksle, aşılamamış bir kültürel-edebi birikim yok sayılır. Hâldeki eksiklikler eski zamana yüklenir; geçmiş yeniden yazılır. Her türlü başarısızlık eskiyle didişerek başarıya dönüştürülür. Evden büyük umutlarla ve hayallerle ayrılan çocuk, gözünü diktiği ufukların yolunu bulamadığı, artık dönecek bir ev de olmadığı için babayı suçlar. Bu, tam da Çocuk Adam'da 'olgunlaşamamak', 'büyümeye direnmek' olarak tanımlanan 'çocuk adamlık' hâlinin itirafıdır.

\section{İmkânsız arzu: Yuvaya dönmek}

Ülkeleri dışında savaşan İsviçreli askerler, memleketlerine dair yanılsamalar, gündüz düşleri, "cansız ve süzgün bir görüntü", "her şeye karşı kayıtsızlık" gibi belirtilerle kendisine getirildiklerinde İsviçreli doktor Johannes Hofer onlardaki rahatsızlığı tanımlamak için 1688'de ilk defa bir terim ortaya atar: nostalji. Yunanca iki kökten meydana gelen sözcük, antik Yunancada bulunmaz. Nostos (eve dönüş) ve algia (özlem), yani eve duyulan özlem anlamiyla bu nev-1̂câd sözcük, "sahte-Yunanca veya nostaljik anlamda Yunancadır" (Boym, 2009: 25). Kaymaklı köy sütünün ve inek çanlarından oluşan gürültünün İsviçreli askerlerde nostaljik tepkiyi özellikle tetiklediğini tespit eden bilim adamları, hastalıktan mustarip olanlar için Alplerde bir tatil, sıcak uyutucu merhemler, afyon veya sülük tedavisi önerirler. Kuşkusuz bunların hiçbiri vatana dönüşün yerini tutmaz ancak Hofer ve arkadaşları hastalığın tedavi edilebileceğine kesinlikle kanaat getirirler. 18. yy'da ulus-devletler çağının arifesinde nostalji evlerinden çok uzakta askerleri, denizcileri ve büyük şehirlere göç etmeye başlayan köylüleri avcunun içine alır. 19. yy'da romantizm akımıyla zirveye ulaşan bu moda hastalık "yurtseverlik ve ulusal ruh anlayışına hem güç veriyor hem de meydan okuyor(dur)" (Boym, 2009: 28). Nostaljinin romantik milliyetçiliğin yakıtı olmaktan modernliğin tedavisi olmayan hastalığına dönüşümünü anlamanın yolunun, birçok ideolojinin "ideal ev" vaadini anlamaktan geçtiğini öneren Boym’a göre nostaljinin tehlikeli yanı, "gerçek evle hayali evi birbirine karıştırma eğiliminde olmasıdır." (2009: 17). Kişisel hafıza ile kolektif hafızanın bu denli iç içe geçtiği böyle bir tasavvurda, kişinin bireysel biyografisiyle ulusun toplumsal biyografisi de birbirine karışır. Yanılsamanın bir kaynağı da budur. Nostalji bu anlamda, "yalnızca eski rejime veya imparatorluğa değil, aynı zamanda geçmişin gerçekleşmemiş düşlerine ve eskiyen gelecek hayallerine duyulan özlemdir" (2009: 17).

Çocuk Adam'ın anlatıcısı, birinci bölümün sonunda artık on sekiz yaşında bir gençtir ve aile, Çengelköy'den İstanbul'a taşınma kararı alır. Toplanıp arabaya yüklenen eşyanın arkasından şaşarak bakan genç anlatıcı bütün aileyi "ilk 
muhaceret devrinde yurdunu terk eden insanlar(a)" benzetir. Yillardan beri içinde yaşanan ev terk edildiği için bütün aile üyeleri üzgündür. Evden çıkılırken "Allah encâmımızı hayretsin!" diye dua eden büyük hanımın duasını anlatıcının annesi içli bir “Amin"le karşılar (Orhon, 1941: 55). ${ }^{4}$

Ancak âkıbet aile için hayırlı olmaz. Koska'daki dört katlı yeni ev, yeni sahiplerinin yerleşmesinin üzerinden fazla geçmeden 23 Temmuz Bayramı sırasında yaşanan Büyük Aksaray Yangını'nda tümüyle kül olur (1941: 68). Aile, “Kadırga'da üç katlı çirkin" (1941: 68) kira evine taşınır. Daha önce, yeni eve taşınma kararının alındığı günlerde eldeki malların ve hâlihazırdaki evin satışı gündeme gelmediğinden kira evine taşınma düşüncesi özellikle ailenin kadınlarını fazlasılyla rahatsız eder. Gerçekten de, eski İstanbul yaşantısında bir ailenin kirada yaşaması hem prestij kaybı hem mülksüzlük anlamına geldiğinden yadırganır. Yeni hayat şartlarının getirdiği toplumsal bir ürün olarak mekânın (Lefebvre, 2014: 23) kiralanması uygulaması, Tanzimat'la beraber geleneksel Türk-İslam kentine girer ve Kiralık Konak örneğinde olduğu gibi bir süre dirençle karşılanır (Bertram, 2012: 153-157). Kirada olmak başta komşular, sonra kiracıların kendisi için bir dışarlık ve yabancılık hâli olarak algılanır. Bu nedenle, yangından arta kalan eşyayla yerleşilen evin "çirkin" diye nitelenmesi boşuna değildir. Aile üyeleri kendilerini burada sığıntı gibi hissederler. Ancak artık yirmi iki yaşında bir delikanlı olan anlatıcı için bunun bir önemi yoktur. $\mathrm{O}$, kısa sürede yeni muhitin sefaletine ve yeni komşulara uyum sağlar. Komşu evin bahçesinde bakıştı̆̆ı Nezahet adındaki kızla girdiği gönül macerası ona her şeyi unutturur. Amcasının Erenköy'de satın aldığı köşk bile başında kavak yelleri esen anlatıcıyı kıskandırmaz (1941: 69). Nitekim, romanın üçüncü bölümünde amcasının ölümü ve onun kızı Malike'yle evliliğinin ardından Erenköy’de Halit Bey Köşkü diye bilinen evin yeni sahibi kendisi olur.

Romanın üçüncü bölümünde arkadaşına yazdığı mektuplardan anlatıcının hep özlediği huzura ve ev ortamına kavuştuğu görülür. Bu, yarı yarıya gerçekleşmiş bir eve dönüş hikâyesidir. Pek çok mitolojik hikâyenin örüntüsünde Cassin' in de tespit ettiği gibi, "Destanlar bir kadından diğerine giderken yazılır." (2018: 55). Anlatıcının evlerden evlere ve kadınlardan kadınlara yaşadığı macera, Odysseus'un, Ponelope'nin kendisini beklediği evde olmasa da sevdiği kadınla bir başka evde tekrar kavuştuğu bir versiyonu olarak düşünülebilir. Anlatıcı, sevdiği kadına ve onun kendisini beklediği eve kavuşur. Ancak yolculuk burada bitmez. Karısıyla ve üvey kızıyla yaşadı̆̆ı evini yine başka bir kadınla (daktilo kız) yaşadığı gönül macerası sonucunda kaybeder ve ebedi

\footnotetext{
${ }^{4}$ Bu serzeniş, romanın yeniden yazılmış versiyonunda son sahnede tekrar hatırlanır. "Bir saltanatın hikâyesi böyle mi biter? Bir milletin varlı̆̆ı böyle mi tarihe karışır?" (Orhon, 1965: 184), (Orhon, 2009: 160). diye düşünen anlatıcı, I. Dünya Savaşı'ndan mağlup çıkan Türk milletinin kaderini yıllar önce İstanbul'a göç eden ailesine benzetir.
} 
saadetten kovulur. Romanın sonunda evsiz ve kimsesiz bir adama dönüşür. Artık dönecek bir ev yoktur. Anlatıcı, macerasının başladı̆̆ı noktaya, çocukluğun geçtiği eve (Orhon'un “Çengelköy” şiirinde gördüğümüz üzere, kurmaca-dışı düzlemde, aradan elli yıl geçtikten sonra nostaljik bir dürtüyle yaptığı lirik ziyareti saymazsak) asla dönemez. Anlatıcı, romanın sonunda yazacağını söylediği kişisel hikâyesiyle anılarını yeniden canlandırır. Burada, incelemenin başında anlatılan çocukluk evi anlatılır. Felakete uğramış, her şeyini kaybetmiş anlatıcı için yuvaya dönmek, Freudyen bir eylem olarak, yuvanın s1caklığ1 ve güvenliğiyle özdeş ana rahmine dönmek anlamına gelir. Daha önce belirtildiği gibi, nostaljik, somut bir mekâna, eve dönmeye çalışmaz aslında; o, çocukluğuna, gençliğine, hiç değişmemesini umduğu zamana, zamanın içinde donmuşçasına bekleyen nesnelere, insanlara dönmek ister. ${ }^{5}$
"[İnsanlar] bundan böyle yaratılışın özeği olmadıkların, bundan böyle iyilik- sever bir Kayranın [orijinal metinde Providence: Tanrı. Ş.Ş.Y.] sevecen kayg-- sinın nesnesi olmadıklarım kabul etmek zorunda kalacaklardır. Ona öylesine sicaklık ve rahatlık veren baba evini terk etmiş bir çocuğun durumunda ola- caklardır. Ama çocukluğun yenilgiye yazgılanmış olduğu doğru değil midir? Insanlar sonsuza dek çocuk kalmazlar, en sonunda dişarıya, 'düşman yaşam'a gitmek zorundadırlar." (Freud, 2000: 44).

Çocuk Adam'ın her bölümünde bir kadınla özdeşleştiğini ifade ettiğimiz ayrı ayrı evlerin ilki, burada Freud'un "baba evi" dediği yerdir. "Baba evi” gerek eril artalanı, gerek geleneksel Türk evi tanımına uygunluğu bakımından analizimizin psikanalitik-sosyolojik silsilesini tamamlamak için Freud'un sunduğu elverişli bir kavramdır. Bu bağlamda, Freud'un yukarıda "düşman yaşam" dediğini, Gürbilek, Türkiye'nin yakın kültürel tarihinde bulduğu kötülük nüvesiyle açıkladığ "hınç" ve "suç" dolu sokaklarla ilişkilendirilebilir (2016: 8).

Her hikâyenin sonunda olduğu gibi evden kaçan çocuk eve dönecek, kapıyı sertçe yumruklayacak, kapıyı açacak babanın yüzüne bütün günahlarını tek tek sayacaktır. Oysa Parla'nın, Cumhuriyet aydınının tam da sorunun kaynağını araştırdığı tarihsel momentte ölümünü haber verdiği baba artık evde değildir. Evden kırk sekiz saatliğine kaçan çocuğun babadan duymayı umduğu ve bir uzlaşmanın başlangıcı olacak "Evine dön! Her şeyi affettik!" (Benjamin, 2011: 14) cümlesi için geç kalınmıştır. Cumhuriyet yazarı kapı açıldı̆̆ında kendisi gibi baba yokluğunda vesayet üstlenmek zorunda kalmış bir "otoriter çocuk" (Parla, 2009: 20) (bu bağlamda, “çocuk adam”), yani Tanzimat yazarını bulacaktır.

\footnotetext{
${ }^{5}$ Kitabın yeniden yazılmış versiyonunda bu istek, özgün metinde rastlamadığımız içten bir özlemle dile getirilir. "Çengelköy'deki evimizi sık sık rüyamda görüyorum. Satmamışız, orada oturuyoruz. Uyanınca özlüyorum. Keşke İstanbul'a taşınmasaydık. Keşke Meşrutiyet ilan edilmeseydi. Keşke harbe girmeseydik, keşke hiç, hiç, hiçbir şeyimiz değişmeseydi..." (Orhon, 1965: 183), (Orhon, 2009: 158). Bu iç çekiş, bireysel nostaljiyle toplumsal nostaljinin, bireysel mekânla toplumsal mekânın iç içe geçtiği çarpıcı edebi anlardan bir diğeridir.
} 


\section{Sonuç}

Türk edebiyatının nirengi noktalarından biri olan Beş Hececiler'in mensubu Orhan Seyfi Orhon edebiyatın pek çok alanında eser vermiş, edebi çok yönlülüğünü gerçek hayatında da sergilemiş bir şairdir. Onun külliyatında en fazla ihmale uğramış eseri olan Çocuk Adam (1941) hayatının -yaklaşık olarak- ilk otuz yılını anı ve roman türlerini melezleyerek verdiği bir romandır. Orhon'un ellili yaşlarının başında ilk defa yayımladığı bu romandaki başkarakterin çocukluk ve kısmen gençlik yıllarının Orhon'un kendi hayatından derin izler taşıdığı görülür. Orhon gibi çocukluğu Çengelköy'de geçen romanın kahramanının çocukluğa dair anıları hep olumlu sahnelerden oluşur. İlk iki bölümü açısından otobiyografik bir roman kabul edilebilecek Çocuk Adam, anlatının devamında Orhon'un tümüyle kurmacaya dayalı bir özellik sergiler. Anlatıcının çocukluğundan başlayarak yetişkin bir bireye dönüşümünü ve okurun elinde tuttuğu eserini ortaya koyuşunu anlatan Çocuk Adam, aynı zamanda Bildungsroman ve Künstlerroman türlerinin metinsel özelliklerine de uyar. Başkarakterin anıları geride bırakılarak hikâyenin ana olay örgüsünü oluşturan entrikanın anlatılmaya başladığı üçüncü bölümde, isimden içeriğe kurulan bir ilişkiyle, ilk defa zikredilen 'çocuk adam' kavramı, çocukluğa olumsuz anlamlar yükler. Anlatıcının yanında çalıştırdığı daktilo kızla yaşadığı gönül macerası sonucunda yuvasının dağılmasıyla da başa gelen felaketin kaynakları çocuklukta aranır. Böylelikle, anlatıda çocukluğa ikinci kez dönülmüş olur.

Çocuk Adam'ı kurgusal bakımdan ilginç kılan bir diğer özeliği kitabın ilk basıminın üzerinden yirmi beş yıl geçmesinin ardından son bölümünün tümüyle değiştirilerek yeniden yayınlanmasıdır. Bunun ardındaki nedenin dönemin okur kitlesi tarafından romanın, yazarın biyografisinin zorunlu bir yansıması olarak kabul edilmesi olabileceği gibi, bu yazıda üzerinde durulmaya çalışıld1ğı gibi, hayal kırıklıkları yaşatan Cumhuriyetçi aydınlanma projesinin geçmişle yüzleşmeyi seçmek yerine, milliyetçi bir Kurtuluş Savaşı anlatısına dönüşerek geçmişe böylece galebe çalma stratejisinin yattığı düşünülebilir. Bunun önemli bir göstergesi olarak, Avrupa dillerinde 1688'de ortaya çıkan 'nostalji' sözcügünün Türkçede ilk kez erken Cumhuriyet döneminde kullanılmaya başlaması dikkat çeker. Bu durum, sözcüğün romanda sık sık hatırlanan 'baba evi' kavramına atıfta bulunmasından hareketle Osmanlı çocuğu-Cumhuriyet aydını arasında metaforik bir bağ kurulmasını sağlar. Yukarıda işaret edilen ilk hatırlama sürecinde baba evinde geçen bir masumiyet çağı olarak resmedilen çocukluk, ikinci hatırlamada bir habaset kaynağı olarak görülür. Bunun da 'nostaljik yanılsama' süreci sonunda ortaya çıkan bir 'sahte anı' sendromu olabileceği kuvvetle muhtemeldir. Orhon'un “Çengelköy” şiirinde de anlattı̆̆ baba evine dönüş eylemi simgesel düzeyde imkânsız bir hesaplaşma çabası- 
dır. Böylelikle, Osmanlı'nın son döneminde siyasi otoritenin, yani padişahın yokluğunda toplumda birer baba kimliğine bürünen Tanzimat yazarı gibi, 'lider kültü'nün yokluğunda erken Cumhuriyet dönemi yazarı da topluma karşı benzer bir rolü üstlenmesi gerektiğini anlar. Ancak yeni rejimin üzerinden henüz çok kısa bir süre geçmişken edebi ve kültürel yetersizliklerini, zihinsel azgelişmişliğini, çocukça iştahlarını "çocuk adam" itirafıyla kabullenmek zorunda kalır. Yarım yamalak bir hafızanın yarım yamalak bir yaşantı ortaya çıkardığı bu çarpıcı Çocuk Adam romanı örneğinde modernleşme projesinin ilk dönem Cumhuriyet aydınında yarattığı hayal kırıklığı eserin bilinçaltından d1şarı taşar.

\section{Kaynakça}

Aksoy, N. (2014). Kurgulanmış benlikler-otobiyografi, kadın, cumhuriyet. İletişim Yayınları.

Atay, O. (2007). Günlük. İletişim Yayınları.

Baydar, M. (2015). Edebiyatçılarımız ne diyorlar? İletişim Yayınları.

Benjamin, W. (2011). Tek yön. (Çev.) Tevfik Turan. Yapı Kredi Yayınları.

Berk, İ. (2019). Poetika. Yapı Kredi Yayınları.

Bertram, C. (2012). Türk evini hayal etmek-eve dair kolektif düşler. (Çev.) Mehmet Ratip. İletişim Yayınları.

Boym, S. (2009). Nostaljinin geleceği. (Çev.) Ferit Burak Aydar. Metis Yayınları.

Cassin, B. (2018). Nostalji-İnsan ne zaman evindedir?-Odysseus, Aeneas, Arendt. (Çev.) Seçil Kıvrak. Kollektif Yayınları.

Emre, İ. (2006). Postmodernizm ve edebiyat. Anı Yayıncılık.

Freud, S. (1996). Olgu İncelemeleri II. (Çev.) Ayhan Eğrilmez. Payel Yayınları.

Freud, S. (2000). Bir yanılsamanın geleceği-uygarlı ve hoşnutsuzlukları. (Çev.) Aziz Yardımlı. İdea.

Gürbilek, N. (2016). Kötü çocuk Türk. Metis Yayınları.

Kahraman, Â. (2007). Orhan Seyfi Orhon, Türkiye Diyanet Vakfi İslâm Ansiklopedisi. TDV Yayınlar1, 33, 389-390.

Karaosmanoğlu, Y. K. (2014). Atatürk. İletişim Yayınları.

Lefebvre, H. (2014). Mekânın üretimi. (Çev.) Işık Ergüden. Sel Yayınları.

McHugh, P. R. (2008). Try to remember: Psychiatry's clash over meaning, memory and mind. Dana Press. 
Muzaffer, S. (1942). Modern âdab-ı muaşeret. İnkılap Kitabevi.

Nişanyan, S. (2010). Nişanyan sözlük-çă̆glaş Türkçenin etimolojisi. Everest Yayınları.

Nişanyan sözlük (t.y.). 30 Temmuz 2020 tarihinde https://www.nisanyansozluk. $\mathrm{com} / ? \mathrm{k}=$ nostalji adresinden erişildi.

Orhon, O. S. (1941). Çocuk adam. Semih Lûtfi Kitabevi.

Orhon, O. S. (1965). Çocuk adam. Rek-Tur.

Orhon, O. S. (1970). Bütün şiirleri. MEB Yayınları.

Orhon, O. S. (2009). Çocuk adam. Everest Yayınları.

Parla, J. (2009). Babalar ve oğullar-Türk romanının epistemolojik temelleri. İletişim Yayınları.

Parla, J. (2011). Türk romanında yazar ve başkalaşım. İletişim Yayınları.

Schachter, D. L. (2002). The seven sins of memory: How the mind forgets and remembers. Mariner Press.

Tarancı, C. S. (1983). Bütün şïrleri. Can Yayınları.

Tuncer, H. (2003). Beş Hececiler. Orkun Kitabevi.

Yalçın, M. (Ed.) (2010). Tanzimat'tan bugüne edebiyatçılar ansiklopedisi-2. Yapı Kredi Yayınları.

Yıldız, A. D. (2010). Popüler Türk romanları. Dergâh Yayınları.

\section{Etik kurul onayı}

Münferit ve edebi konulu bir inceleme olan bu makale, özel ve tüzel 3. tarafları maddi/manevi bakımdan ilgilendirmemesi sebebi ile etik kurul izni gerektirmeyen çalışmalar arasında yer almaktadır.

\section{Çıkar çatışması beyanı}

Bu çalışmada herhangi bir potansiyel çıkar çatışması bulunmamaktadır. 